\title{
Stan inteligencji środowiskowej studentów z Polski, Słowacji, Czech i Ukrainy
}

\section{KEYWORDS}

environmental intelligence, environmental personality, environmental protection, sociological research, interdisciplinary

\begin{abstract}
Cynk Karolina, Stan inteligencji środowiskowej studentów z Polski, Słowacji, Czech i Ukrainy [State of environmental intelligence students from the Poland, Slovakia, the Czech Republic and Ukraine]. Kultura - Społeczeństwo Edukacja nr 2(14) 2018, Poznań 2018, pp. 221-243, Adam Mickiewicz University Press. ISSN 2300-0422. DOI 10.14746/kse.2018.14.16.
\end{abstract}

Article consists from two part - theoretical, which contain conceptualization of basic concepts and empirical, in which have been presented investigative hypotheses and analysis of the data obtained results conducted research in Poland, Slovakia, Czech Republic and Ukraine in 2015. The subject of the research was: "Environmental values in the awareness of the students of humanities and life sciences from the selected European countries".

Formulate conclusions are pessimistic enough. They indicate, that level of evolution of environmental intelligence is low among students, accompanies also deficit of feature of so called environmental personality ago. The highest level of environmental intelligence have presented non-believers and persons declaring other confession. In second variable they were inhabitants of cities. Results they should present impulse for taking of next research in this range.

\section{Wstęp}

W trakcie ewolucji człowieka wiele jego organów ulegało modyfikacji; do pewnego czasu sukcesywnie zwiększała się chociażby objętość i masa ludzkiego mózgu. Faktu tego nie należy utożsamiać z konsekwentnym rozwojem zdolności umysło- 
wych człowieka; gdy ten jednak przyspieszył, homo sapiens posiadł zdolność rozwijania kultury, co pozwoliło mu przetrwać.

Mimo że ludzki mózg jest wciąż nie do końca zbadanym organem, liczne informacje, jakie świat nauki zebrał na przestrzeni lat, pozwalają stwierdzić, iż to w nim - ogólnie rzecz ujmując - umiejscowiona jest inteligencja. Fascynuje on człowieka od czasów starożytnych, kiedy to ludzie zaczęli porównywać się zarówno z innymi zwierzętami, jak i z innymi osobami. Szybko okazało się, że pod względem sprawności w zakresie myślenia, rozumowania i innych procesów poznawczych istoty ludzkie różnią się nie tylko od zwierząt, ale także między sobą. To, jak bardzo ludzie są odmienni, a także źródła tych różnic oraz sposób ich opisania stanowi przedmiot zainteresowań wielu fachowców zajmujących się zagadnieniem ludzkiej inteligencji. Skromną ambicją niniejszej pracy jest zbadanie tego zagadnienia, choć w bardzo wąskim wymiarze, a mianowicie związku inteligencji z kwestią ochrony przyrody.

\section{Istota inteligencji środowiskowej}

Zrozumienie terminu inteligencja środowiskowa wymaga uprzedniego wyjaśnienia pierwszego członu tego wyrażenia. Warto nadmienić, że pojęcie inteligencji jest bardzo trudne do zdefiniowania, jednak w celu uzyskania pewnego ogólnego poglądu na temat tego, czym ona jest, warto przywołać poglądy prekursora w dziedzinie badań nad inteligencją - sir Francisa Galtona, który uważał, że konstytuują ją dwie cechy: energia działania i wrażliwość zmysłowa. Pierwsza z nich jest niezbędna do wykonywania pracy umysłowej, druga pozwala odbierać informacje z otoczenia, które, odpowiednio wykorzystane, umożliwiają adaptację do warunków środowiskowych (Nęcka, 2003: 15-16). Mimo że obecnie również sięga się do tego tradycyjnego rozumienia zdolności umysłowej, mocniejszy akcent kładzie się na nieco inne jej aspekty. Według amerykańskiej psycholog Lindy Gottfredson inteligencja stanowi ogólną zdolność umysłową, dotyczącą umiejętności rozumowania, planowania, rozwiązywania problemów, myślenia abstrakcyjnego, pojmowania złożonych kwestii oraz szybkiego uczenia się - także na podstawie własnego doświadczenia (Gottfredson, 1997: 13). Ujęcie to wskazuje, iż istotą inteligencji jest zdolność radzenia sobie z nowymi oraz złożonymi wymiarami sytuacji, jakie spotykają człowieka. Inteligencja jest zatem cechą zgeneralizowaną, czyli ujawniającą się w różnych sytuacjach i zadaniach intelektualnych. Zdolności umysłu zasługują na miano cech, ponieważ przejawiają się w pewnej klasie zadań, a więc do pewnego stopnia są uogólnione. Gwoli ścisłości cechę należy zatem uznać za 
„względnie stałą, charakterystyczną dla jednostki, zgeneralizowaną tendencję do określonych zachowań, przejawiającą się w różnych sytuacjach" (McCrae, Costa, 1995: 232). Cechami w tym ujęciu nie są tylko właściwości intelektu człowieka (poziom sprawności w zakresie myślenia, rozumowania i innych procesów poznawczych), ale także jego osobowość i temperament. Cechy temperamentu to przede wszystkim wrodzone właściwości układu nerwowego, determinujące formalną charakterystykę zachowań człowieka, taką jak aktywność czy reakcje na bodźce. Cechy osobowości z kolei to typowe sposoby zachowania człowieka w sytuacjach emocjonalnych i społecznych (Nęcka, 2003: 14). Ten ostatni rodzaj cech - z punktu widzenia podejmowanej problematyki - jest szczególnie interesujący, ponieważ nawiązuje on do funkcjonującego w literaturze przedmiotu, wyrażenia tak zwanej osobowości środowiskowej. Sam termin osobowość oznacza

zespół cech warunkujących spójność zachowania i tożsamości jednostki. Pod względem nasilenia i konfiguracji tych cech, które kształtują się w toku interakcji czynników genetycznych i środowiskowych oraz tworzą strukturę osobowości (...) występują różnice indywidualne. One to współdecydują o specyficznym dla jednostki przystosowaniu do wymagań środowiska (...). (Strelau, Doliński, 2010: 799)

Psycholodzy i socjolodzy kultury do zespołu cech charakteryzujących wspomniany typ osobowości środowiskowej zaliczają: otwartą (ekstrawertyczną) i życzliwą postawę wobec innych istot, uczciwość, czułość, uczuciowość, uczynność, skromność, ugodowość, tolerancyjność, sumienność, kontemplację, empatię, odporność na stres, holistyczny sposób postrzegania świata, wrażliwość na piękno przyrody, gotowość i umiejętność działania w jej obronie, styl życia zgodny z przyjętą hierarchią wartości - bardziej duchowych niż konsumpcyjnych (Kalinowska, 1993: 298). Niektóre z wymienionych cech tworzą wręcz podstawę struktury ludzkiej osobowości; amerykański psycholog Lewis Goldberg zaliczył do nich: ekstrawersję, ugodowość, sumienność, stałość emocjonalną i intelekt (Goldberg, 1993: 26-27).

Wracając do zagadnienia inteligencji: warto zauważyć, że nie jest ona postrzegana jedynie przez pryzmat jednego rodzaju monolitycznej zdolności, w dodatku ściśle powiązanej z rozumowaniem przy użyciu abstrakcyjnych symboli. Udowodnić próbował to amerykański psycholog Howard Gardner, który zaproponował teorię wielu inteligencji, zawierającą siedem różnych zdolności, takich jak: inteligencję językową, matematyczno-logiczną, muzyczną, kinestetyczną, przestrzenną, intrapersonalną (emocjonalną) i interpersonalną (społeczną) (Gardner, 1983: 38-49). Później dodał on do listy wspomnianą już inteligencję przyrodniczą (środowiskową). Pomocne przy rozwoju tej ostatniej jest bezpośrednie doświadczanie i poznawanie przyrody poprzez odbieranie przy użyciu wszelkich zmysłów, wysyłanych przez środowisko 
bodźców. Poznanie uwrażliwienia i emocjonalności skierowanych na świat wartości przyrodniczych, a także silniejsze doświadczanie pogarszającego się stanu środowiska przyrodniczego, niektórzy określają jako przejaw swoistego rodzaju zdolności umysłowej zwanej właśnie inteligencją środowiskową (Louv, 2005: 98). Należy podkreślić, że przy odwoływaniu się do niej nie chodzi o samą wzbudzoną wrażliwość, której przedmiotem jest przyroda, gdyż ta sama w sobie nie jest jeszcze inteligencją, ale o istotę w postaci myślenia, uświadomienia sobie czy zrozumienia tego uwrażliwienia i uczuciowości skierowanych na świat wartości przyrodniczych i ochronę środowiska. Konsekwencją tego poznania powinno być wykorzystywanie tej zdolności umysłowej do rozwiązywania złożonych problemów dotyczących ochrony środowiska przyrodniczego (Squalli, 2014: 34).

Z kolei inny amerykański psycholog - Daniel Goleman - wyróżnił inteligencję ekologiczną, której jednak nie należy do końca utożsamiać - choć granica nie jest ostra - z inteligencją środowiskową. Inteligencja ekologiczna oznacza zdolność przystosowania się do zajmowanej przez człowieka ekologicznej niszy. „Ekologiczna” odnosi się w tym przypadku do zrozumienia tego, jak funkcjonuje przyroda, natomiast „inteligencja” znaczy umiejętność uczenia się na podstawie doświadczenia i racjonalnego obchodzenia się ze środowiskiem. Inteligencja ekologiczna polega zatem na zrozumieniu, zaakceptowaniu, a następnie zastosowaniu w praktyce teorii pozwalającej człowiekowi znaleźć swoje miejsce w przyrodzie (Goleman, 2009: 44).

Rozwijanie inteligencji środowiskowej wymaga dostrzeżenia kruchości bytu przyrodniczego i głębszego doświadczania oraz przeżywania szkód wyrządzanych przez człowieka otoczeniu przyrodniczemu, zwłaszcza gdy ich bezpośrednie skutki nie są jeszcze odczuwalne. Odbieranie tych doznań - jakkolwiek przykrych dla ludzi o prawym charakterze - przyczynia się do pełniejszego przeżywania człowieczeństwa, uszlachetnienia i wszechstronniejszego rozwoju istoty ludzkiej - zarówno w sferze fizycznej, intelektualnej, zmysłowej, jak i emocjonalnej. Wzbudzenie u ludzi pozytywnych uczuć względem przyrody oraz refleksji i współczucia w sytuacji jej złej kondycji stanowi znaczne wyzwanie dla tych, którzy podejmują inicjatywy mające na celu rozwijanie i pobudzanie zdolności umysłu skierowanych na kwestie ochrony przyrody (Czartoszewski, 2001: 38).

\section{Metoda badawcza i analiza danych empirycznych}

Stan inteligencji środowiskowej prezentowany przez członków danego społeczeństwa można określić jedynie na podstawie badań naukowych. Jedno z takich socjologicznych badań zostało przeprowadzone w okresie od 13 kwietnia do 
16 października 2015 roku. Temat tego projektu badawczego brzmiał: „Wartości ekologiczne $\mathrm{w}$ świadomości studentów nauk humanistycznych i przyrodniczych z wybranych państw europejskich". W wyniku zrealizowania projektu zebrane zostały dane dotyczące między innymi: prezentowanej przez studentów wiedzy z zakresu ochrony przyrody, jej zagrożeń oraz ich wagi; deklarowanych poglądów na temat stanu środowiska przyrodniczego; prezentowanego przez respondentów poziomu tzw. kultury środowiskowej, w tym akceptowanych norm i wartości ekologicznych oraz umiejscowienia ich wśród innych społecznych dóbr, cenionych przez studentów; deklarowanych postaw względem środowiska przyrodniczego oraz w miarę możliwości - przejawianej w sposób świadomy - wrażliwości i stanu emocjonalnego badanych, względem problemów środowiskowych, a także cech osobowościowych respondentów, którym leży na sercu dobro przyrody.

Najważniejsze problemy badawcze, skupiające się głównie na zbadaniu poziomu wykształcenia u studentów inteligencji środowiskowej, sformułowane zostały w następujący sposób: Czy respondenci posiadają zdolność myślenia w kategoriach holistycznych? Jakie emocje towarzyszą respondentom $\mathrm{w}$ trakcie poruszania zagadnień z zakresu ochrony przyrody? Czy tematyka dotycząca troski o środowisko wzbudza u badanych optymizm, czy raczej pesymizm społeczny? Co motywuje studentów do dbania o naturę? Jakim elementom przyrody przysługuje, zdaniem respondentów, status moralny? Czy badane osoby opowiadają się za założeniami egalitaryzmu gatunkowego? Jakie cechy osobowościowe przejawiają respondenci deklarujący troskę o środowisko przyrodnicze?

Powyższym problemom badawczym odpowiadają sformułowane w następujący sposób wstępne i ogólne hipotezy badawcze: Studenci w pewnej mierze przejawiają holistyczny sposób myślenia o środowisku przyrodniczym, gdyż mają oni świadomość, że ekosystem jest jedną całością składającą się z połączonych i oddziałujących na siebie elementów. Tematyka dotycząca stanu środowiska przyrodniczego na ogół wywołuje u respondentów negatywne emocje, takie jak: lęk, strach, niepewność czy niepokój, dzieje się tak z tego powodu, iż w ich opinii przyroda znajduje się w złej kondycji. Poruszanie zagadnień ochrony środowiska wywołuje u jednostek raczej negatywne odczucia, co w ogólnym bilansie skutkuje przejawianiem się ogólnospołecznego pesymizmu wśród badanych. Najbardziej do troski o środowisko studentów motywują doraźne korzyści, jakie człowiek może uzyskać i które ujawniają się na przykład w możliwości poprawienia jakości swojego życia. W opinii badanych status moralny, który niewątpliwie należy się człowiekowi, powinno się również przypisać zwierzętom, z tego względu, iż są to stworzenia szczególnie wrażliwe na ból. Mimo że studenci są na ogół skłonni, by nadać im wartość autoteliczną, to raczej nie opowiadają się za całkowitym egali- 
taryzmem gatunkowym. Wyniki zrealizowanych badań do końca nie pozwalają udzielić odpowiedzi na pytanie dotyczące wskazania zbioru cech osobowościowych respondentów deklarujących poparcie dla działań na rzecz ochrony środowiska przyrodniczego, niemniej z pewnym prawdopodobieństwem można stwierdzić, że badani ci charakteryzują się między innymi: uczuciowością, otwartością, tolerancyjnością, kontemplacją czy życzliwością wobec innych istot.

Na uwagę zasługuje fakt, iż projekt został zrealizowany w oparciu o przyjętą metodologię, zgodnie z którą badania przeprowadzono na próbie celowej 520 studentów. Próbę tę stanowiły osoby studiujące w Uniwersytecie Rzeszowskim (Polska), Uniwersytecie Preszowskim (Słowacja), Rówieńskim Państwowym Uniwersytecie Humanistycznym (Ukraina) oraz Uniwersytecie Ostrawskim (Czechy). Dobór uczelni został dokonany na podstawie tak zwanej metody kuli śniegowej. W każdym z wymienionych uniwersytetów przebadano po 130 osób, w tym połowę stanowili studenci nauk humanistycznych bądź społecznych natomiast drugą połowę - studenci nauk przyrodniczych. Osoby badane były słuchaczami studiów licencjackich lub inżynierskich (z wyjątkiem studentów I roku) oraz studentami studiów magisterskich. Wszyscy przebadani respondenci studiowali w trybie stacjonarnym (dziennym). Kierunkami, na jakich zrealizowano badania były natomiast - w przypadku nauk humanistycznych i społecznych: praca socjalna (w Polsce III rok I stopnia, na Słowacji I rok II stopnia, II rok I i II stopnia), kulturoznawstwo (w Polsce I i II rok II stopnia), politologia (w Polsce II rok II stopnia), andragogika (na Słowacji II i III rok I stopnia i II rok II stopnia), filologia (w Czechach I i II rok II stopnia) i historia (na Ukrainie III i IV rok I stopnia, w Czechach II rok I stopnia), a w przypadku nauk przyrodniczych: technologia żywności i żywienie człowieka (w Polsce III rok I stopnia), biologia (na Słowacji I rok II stopnia i II rok I i II stopnia, na Ukrainie II i III rok I stopnia, w Czechach I rok II stopnia), ekologia (na Słowacji I rok II stopnia i II rok I i II stopnia, na Ukrainie III rok I stopnia), ochrona środowiska (w Polsce I i II rok, II stopnia, w Czechach II rok I stopnia, I i II rok II stopnia), rolnictwo (w Polsce I rok II stopnia), geografia (w Czechach II i III rok I stopnia, I i II rok II stopnia) oraz kartografia (w Czechach II rok I stopnia). 19,8 \% badanych stanowili studenci biologii, $15,4 \%$ - historii, $14,6 \%$ - pracy socjalnej, 7,9\% - filologii 7,5\% - ekologii, 6,7\% - geografii, 6,2\% - technologii żywności i żywienia człowieka, 5,8\% - ochrony środowiska, 5,4\% - andragogiki, 4,6\% - kulturoznawstwa, 2,7\% - rolnictwa, 1,7\% - kartografii, 1,7\% - politologii. Wybór kierunków, na jakich zrealizowano badania, został dokonany na podstawie doboru przypadkowego, co oznacza, że przebadano studentów tych kierunków, na których, zgodnie z planem studiów, były w danym czasie realizowane zajęcia dydaktyczne. Ponadto studenci studiów 
licencjackich stanowili $62,9 \%$ badanych, natomiast magisterskich - 37,1\%; przy czym 29,2\% osób stanowili studenci III roku studiów licencjackich, 28,0\% - adepci I roku studiów magisterskich, 24,3\% - II roku studiów licencjackich, 9,4\% - IV roku studiów licencjackich (w przypadku Ukrainy) oraz 9,0\% - drugiego roku studiów magisterskich. Dokonując bliższej charakterystyki przebadanej próby, należy również nadmienić, że $74,6 \%$ osób badanych stanowiły kobiety, a 25,4\% - mężczyźni; 56,0\% badanych to osoby, które znajdowały się w wieku 20-22 lata, 32,7\% stanowiły osoby w wieku 23-25 lat, 7,3\% - w wieku 17-19 lat, natomiast 4,0\% to osoby powyżej 25 . roku życia. Ponadto $55,1 \%$ badanych to studenci, którzy deklarowali, iż na stałe mieszkają na wsi, natomiast $44,9 \%$ - w mieście. Respondenci, którzy uznali się za osoby wierzące, stanowili $82,1 \%$ badanych (w tym 52,2\% stanowili katolicy, $22,2 \%$ - studenci wyznania prawosławnego oraz 7,7\% badanych to respondenci będący innego wyznania), natomiast osoby niewierzące stanowiły 17,9\% respondentów. Z kolei 65,9\% osób to badani, którzy deklarowali, iż żyli na średnim poziomie, $19,4 \%$ studentów żyło w dostatku, a 14,7\% - na skromnym poziomie. Ponadto aż $64,5 \%$ respondentów stanowili studenci, którzy nie umieli określić swoich poglądów politycznych, 15,0\% osób stanowili badani o poglądach prawicowych, 10,0\% badanych to osoby, które stwierdziły, że mają poglądy lewicowe, 5,8\% studentów stanowili respondenci, którzy przyznali się do poglądów centrowych, a 4,7\% - do jeszcze innych. Warto również nadmienić, że obywatelstwo osób badanych praktycznie pokrywało się z krajem, w którym studiowali.

W celu rozstrzygnięcia postawionych problemów badawczych i weryfikacji zaprezentowanych hipotez posłużono się metodą audytoryjnego badania ankietowego. Narzędzie badawcze stanowił kwestionariusz ankiety zawierający 18 pytań zamkniętych i półotwartych. W celu sprawdzenia poprawności skonstruowanego narzędzia w marcu 2015 roku przeprowadzono badanie pilotażowe na 18 studentach Uniwersytetu Rzeszowskiego. Badani ci byli studentami II roku studiów magisterskich - stacjonarnych, na kierunku filozofia. W wyniku przeprowadzonego pilotażu dokonano drobnych korekt głównie w kafeterii niektórych pytań. Pilotaż wykazał również trudności w rozumieniu przez studentów wyrażenia „status moralny"; z tego powodu w badaniach każdorazowo tłumaczono respondentom znaczenie owego zwrotu. Uzyskane dane posłużyły do odpowiednich obliczeń, których dokonano w programie statystycznym IBM SPSS Statistics, przy założeniu granicy błędu na poziomie $\mathrm{p}=0,05$.

Wybrane pytania i uzyskane dane - z uwzględnieniem zmiennych: deklarowane wyznanie oraz stałe miejsce zamieszkania - zostały przedstawione na kolejnych stronach. Należy ponadto nadmienić, że ze względu na dość jednolitą grupę poddaną badaniu, jak i dość jednorodne odpowiedzi, jakie uzyskano, dokonano 
połączenia niektórych kategorii w kafeterii. W przypadku zmiennej: deklarowane wyznanie połączono dwie najmniej liczne kategorie, a mianowicie protestantów i osoby innych wyznań - zazwyczaj wierzących, ale niezwiązanych z jakimś konkretnym Kościołem. Z kolei w przypadku zmiennej: stałe miejsce zamieszkania połączono kategorie miast pierwotnie podzielone na: do 49 999, do 99 999, do 199999 i powyżej 200000 mieszkańców - w jedną ogólną.

W celu przeprowadzenia analizy wybrano pytania, które pozwalają uzyskać dane odnośnie elementów składających się na świadomość środowiskową. Autor posłużył się cechami wyróżnionymi przez H. Gardnera (1983: 38-49) i R. Louv (2005: 98): przejawianymi emocjami, wartościami i równością międzygatunkową. Informacji na temat tych pierwszych dostarcza pytanie dotyczące odczuć związanych ze zmianami dokonującymi się w środowisku. W przypadku wartości respondenci odpowiadali na pytanie odnoszące się do motywów skłaniających do ochrony środowiska. Z kolei informacji o stosunku do równości międzygatunkowej dostarczyło pytanie odnoszące się do statusu moralnego istot innych niż ludzkie oraz to, dotyczące preferowanego twierdzenia religijnego i moralnego. $\mathrm{Na}$ podstawie wybranych założeń H. Gardnera i R. Louv skonstruowane zostało narzędzie badawcze i przeprowadzona została analiza ilościowa.

Tabela 1. Dane dotyczące wyrażanego przez badanych niepokoju o stan przyrody

\begin{tabular}{|l|c|c|c|c|}
\hline \multicolumn{5}{|c|}{ Czy zmiany klimatyczne budzą Twoje obawy? } \\
\hline & katolicy & prawosławni & niewierzący & innych wyznań \\
\hline Zdecydowanie tak & 30,4 & 17,9 & 27,5 & 31,6 \\
\hline Raczej tak & 49,0 & 62,5 & 49,5 & 44,7 \\
\hline Raczej nie & 14,8 & 9,8 & 18,7 & 18,4 \\
\hline Zdecydowanie nie & 3,4 & 4,5 & 2,2 & 2,6 \\
\hline Trudno powiedzieć & 2,3 & 5,4 & 2,2 & 2,6 \\
\hline \multicolumn{1}{|c|}{ Czy przyszła egzystencja gatunku ludzkiego budzi Twoje obawy? } \\
\hline Zdecydowanie tak & 29,5 & 4,6 & 25,3 & 23,7 \\
\hline Raczej tak & 31,8 & 50,0 & 23,1 & 23,7 \\
\hline Raczej nie & 23,1 & 13,0 & 33,0 & 21,1 \\
\hline Zdecydowanie nie & 4,9 & 0,9 & 16,5 & 15,8 \\
\hline Trudno powiedzieć & 10,6 & 31,5 & 2,2 & 15,8 \\
\hline
\end{tabular}

Źródło: badania własne ${ }^{1}$

${ }^{1}$ Badania sfinansowane zostały z dotacji celowej MNiSW, nr projektu: IS-01/2015/508. 
Rozkład odpowiedzi zobrazowany w tabeli 1 pozwala w pewnym stopniu zapoznać się z zaprezentowanym przez badanych holistycznym sposobem myślenia, a także przejawianymi przez nich uczuciami i emocjami, jakie towarzyszyły respondentom w sytuacji poruszania zagadnień z zakresu ochrony środowiska przyrodniczego. Należy zaznaczyć, że myślenie w kategoriach holistycznych oznacza umiejętność objęcia umysłem wielu oddziałujących na siebie elementów, w tym przypadku łączących się w jedną całość (ekosystem). Przystępując do analizy pierwszej kwestii, można zauważyć, że zdecydowana większość studentów - bez względu na deklarowane wyznanie - obawiała się zmian klimatycznych. Zważywszy, że jest to proces długotrwały, można przypuszczać, iż żywiony przez studentów niepokój dotyczył głównie przyszłych konsekwencji tych zmian. Przejawianie świadomości oraz prezentowanie wyobraźni dotyczącej skutków chociażby zmian klimatu, nie tylko w wymiarze czasowym, ale i przestrzennym, w pewnej mierze stanowią wskaźniki poziomu holistycznego sposobu myślenia osób badanych. O tego rodzaju zdolności jeszcze dobitniej świadczą odpowiedzi na drugie pytanie, dotyczące obaw związanych z przyszłą egzystencją gatunku ludzkiego. W tej kwestii większość katolickich i prawosławnych studentów żywiło niepokój związany z tą wizją, przy czym prawie 1/3 osób przyznających się do wyznania prawosławnego nie umiało się w tej sprawie wypowiedzieć. Z kolei większości niewierzących i osób innych wyznań ta kwestia raczej nie martwiła. Warto również zauważyć, że wśród studentów - bez względu na wyznanie - zmiany klimatu wywoływały niepokój u większej liczby respondentów niż przyszłe losy człowieka na Ziemi. Ponadto na podstawie uzyskanych danych można stwierdzić, że zwłaszcza kwestia zmian klimatycznych u znacznej części osób badanych wzbudzała negatywne emocje w postaci lęku, strachu i niepewności. Można zatem stwierdzić, że poruszanie zagadnień dotyczących ochrony i zagrożeń środowiska wiązało się na ogół z dyskomfortem psychicznym doświadczanym przez znaczną część respondentów, który w ogólnym bilansie przejawiał się w postaci pesymizmu społecznego. Pewien wyjątek stanowiły jedynie wspomniane już osoby niewierzące i przyznające się do innych wyznań, dla większości, których zwłaszcza kwestia dalszej egzystencji ludzkiej nie wywoływała powszechnego pesymizmu. W przypadku drugiego pytania rachunek statystyczny pozwala na dokonanie dokładniejszej analizy uzyskanych danych i przeprowadzenia testu chi-kwadrat, w wyniku którego uzyskano wartość $\chi^{2}(12)=101,109 ; p<0,05$. Otrzymany wynik pozwala przyjąć hipotezę, zgodnie z którą zmienna: deklarowane wyznanie koreluje z wyrażanymi przez respondentów obawami względem przyszłej egzystencji człowieka na Ziemi. Siłę związku między tymi zmiennymi można uznać za mocną, gdyż wartość współczynnika kontyngencji Pearsona wyniosła $\mathrm{C}=0,410$. 
Tabela 2. Dane dotyczące wyrażanego przez badanych niepokoju o stan przyrody

\begin{tabular}{|l|c|c|}
\hline \multicolumn{3}{|c|}{ Czy zmiany klimatyczne budzą Twoje obawy? } \\
\hline & wieś & miasto \\
\hline Zdecydowanie tak & 30,8 & 22,9 \\
\hline Raczej tak & 48,4 & 55,5 \\
\hline Raczej nie & 14,7 & 15,0 \\
\hline Zdecydowanie nie & 3,2 & 3,5 \\
\hline Trudno powiedzieć & 2,9 & 3,1 \\
\hline \multicolumn{1}{|c|}{ Czy przyszła egzystencja gatunku ludzkiego budzi Twoje obawy? } \\
\hline Zdecydowanie tak & 25,1 & 20,2 \\
\hline Raczej tak & 33,8 & 32,9 \\
\hline Raczej nie & 20,0 & 26,3 \\
\hline Zdecydowanie nie & 5,5 & 8,8 \\
\hline Trudno powiedzieć & 15,6 & 11,8 \\
\hline
\end{tabular}

Źródło: badania własne

Analiza danych przedstawionych w tabeli 2 wskazuje, iż wyższy odsetek badanych - stanowiących zarówno mieszkańców miast, jak i wsi - wyrażało obawy w stosunku do zmian klimatycznych niż do przyszłej egzystencji gatunku ludzkiego. Niemniej w obu przypadkach większość respondentów wykazywała przejawy myślenia w kategoriach holistycznych. Negatywne emocje towarzyszące badanym przy poruszaniu wspomnianych kwestii świadczą o ogólnie panującym wśród nich pesymizmie społecznym. W wyniku dokonania głębszej analizy wyrażanych przez studentów uczuć względem zmian klimatycznych przeprowadzono test chi-kwadrat, którego wartość wyniosła $\chi^{2}(4)=4,166 ; p=0,384$. Uzyskany wynik nakazuje odrzucić hipotezę zakładającą, że żywione przez badanych obawy co do zmian klimatycznych zależą od ich stałego miejsca zamieszkania. W przypadku drugiej kwestii wartość testu chi-kwadrat wyniosła $\chi^{2}(4)=6,785$; $\mathrm{p}=0,148$. Wynik ten również nie jest istotny statystycznie, co oznacza, iż należy odrzucić hipotezę zakładającą występowanie korelacji między zmienną: stałe miejsce zamieszkania oraz żywionymi obawami wobec przyszłej egzystencji gatunku ludzkiego. 
Tabela 3. Dane dotyczące motywów, jakimi zgodnie z deklaracjami kierowali się badani chroniący przyrodę

\begin{tabular}{|l|c|c|c|c|}
\hline \multicolumn{5}{|c|}{ Z jakich powodów należy Twoim zdaniem troszczyć się o środowisko przyrodnicze? } \\
\hline & katolicy & prawosławni & niewierzący & innych wyznań \\
\hline $\begin{array}{l}\text { Dla poprawienia jakości życia } \\
\text { ludzkiego }\end{array}$ & 19,7 & 20,2 & 12,8 & 11,0 \\
\hline $\begin{array}{l}\text { By ograniczyć ryzyko zapad- } \\
\text { nięcia na choroby cywiliza- } \\
\text { cyjne }\end{array}$ & 12,4 & 14,0 & 6,4 & 9,8 \\
\hline $\begin{array}{l}\text { By zmniejszyć liczbę katastrof } \\
\text { ekologicznych }\end{array}$ & 9,7 & 15,7 & 10,4 & 9,8 \\
\hline Dla dobra zwierząt & 9,1 & 1,5 & 8,1 & 6,1 \\
\hline Dla piękna przyrody & 7,0 & 1,8 & 4,6 & 5,0 \\
\hline $\begin{array}{l}\text { Dla wewnętrznej wartości } \\
\text { samej natury }\end{array}$ & 3,4 & 2,9 & 11,5 & 11,0 \\
\hline $\begin{array}{l}\text { By pozostawić przyrodę w jak } \\
\text { najlepszym stanie następnym } \\
\text { pokoleniom }\end{array}$ & 20,5 & 18,9 & 19,6 & 22,4 \\
\hline $\begin{array}{l}\text { By nie unicestwić życia na } \\
\text { Ziemi }\end{array}$ & 18,1 & 25,0 & 26,6 & 24,9 \\
\hline
\end{tabular}

Źródło: badania własne

Rozkład odpowiedzi przedstawiony w tabeli 3 wskazuje, iż najwięcej osób opowiadających się za traktowaniem przyrody w sposób instrumentalny, czyli pozwalający uzyskać człowiekowi - tak w rozumieniu jednostkowym, jak i gatunkowym - korzyści, przejawiali wyznawcy prawosławia oraz katolicy; świadczy o tym stosunkowo znaczna liczba wskazań dwóch pierwszych oraz przedostatniego motywu przedstawionego w tabeli. Natomiast osoby niewierzące stanowiły najwyższy (choć stosunkowo niski) odsetek osób, które były skłonne chronić przyrodę ze względu na jej piękno, wewnętrzną wartość, a także dla dobra zwierząt, jak również w celu zachowania życia na Ziemi. Można przypuszczać, że poglądom tych osób towarzyszyło przejawianie takich cech osobowości, które zaliczone zostały do osobowości środowiskowej jak np. skromność, uczuciowość czy życzliwość wobec innych stworzeń. Należy zwrócić uwagę, że ten ostatni, dość często wskazywany przez respondentów motyw, skupia w sobie kilka elementów, a mianowicie holistyczny sposób myślenia, niepewność co do dalszych losów stworzeń zamieszkujących Zie- 
mię i troskę o przyrodę. W pewnym sensie znaczny odsetek osób, które wybrały tę odpowiedź - bez względu na deklarowane wyznanie - może napawać optymizmem. Prezentowana przez studentów wrażliwość i wyobraźnia dotycząca zagrożeń przyrodniczych odgrywała pewną rolę w kształtowaniu się ich inteligencji środowiskowej, choć z drugiej strony, inne równie ważne wartości nie tylko estetycznego, ale i symbolicznego oraz poznawczego typu zwłaszcza wśród wyznawców prawosławia uzyskały bardzo niski odsetek wskazań. Można również wnioskować, że zapewne znaczna część studentów zwłaszcza wyznania prawosławnego nie przejawiała większości cech charakterystycznych dla osobowości środowiskowej. Ogólnie można stwierdzić, że poziom rozwoju inteligencji środowiskowej wśród osób badanych, który wymaga zrozumienia, ogólnie rzecz ujmując, emocjonalności skierowanej na świat przyrodniczy - jest raczej niezadowalający, przy czym jej największy potencjał przejawiały osoby niewierzące, a najmniejszy respondenci prawosławni.

Tabela 4. Dane dotyczące motywów, jakimi zgodnie z deklaracjami kierowali się badani chroniący przyrodę

\begin{tabular}{|l|c|c|}
\hline \multicolumn{2}{|c|}{ Z jakich powodów należy Twoim zdaniem troszczyć się o środowisko przyrodnicze? } \\
{$[\%]$}
\end{tabular}

Źródło: badania własne

Analiza danych przedstawionych w tabeli 4 - podobnie jak w przypadku kryterium: deklarowane wyznanie - świadczy o tym, iż główną wskazywaną przez studentów motywacją skłaniającą ich do troski o przyrodę, były przesłanki partykularne, czyli spodziewane korzyści, jakie człowiek może zyskać, chroniąc środo- 
wisko. Różnice w odsetku wskazań dokonanych przez mieszkańców wsi i miast, a odnoszących się tak do motywów, w przypadku których beneficjentem był zarówno człowiek, jak i przyroda, są nieznaczne. Odnośnie do tych „altruistycznych motywów" stosunkowo największą różnicę w liczbie wskazań można zaobserwować w przypadku odpowiedzi: „dla piękna przyrody” oraz „dla wewnętrznej wartości samej natury”. W celu określenia poziomu inteligencji środowiskowej respondentów należy dodatkowo uwzględnić odpowiedź: „dla dobra zwierzą̧"; na tej podstawie można stwierdzić, że jej stan jest podobny u mieszkańców wsi i miast, ze wskazaniem na tych drugich. Zbliżony odsetek wskazań dotyczył też przejawianej przez respondentów skłonności do myślenia w kategoriach holistycznych, o czym może świadczyć świadomość studentów odnosząca się do istnienia długofalowych skutków takiego stanu środowiska przyrodniczego, jaki zostanie pozostawiony kolejnym pokoleniom oraz innym formom życia. Tym samym można wnioskować, że zmienna: stałe miejsce zamieszkania raczej nie korelowała $\mathrm{z}$ prezentowanym poziomem rozwoju inteligencji środowiskowej badanych.

Tabela 5. Dane dotyczące skłonności studentów do przydzielenia statusu moralnego wybranym elementom przyrody

\begin{tabular}{|l|c|c|c|c|}
\hline \multicolumn{5}{|c|}{ Czy Twoim zdaniem zwierzętom przysługuje status moralny? } \\
\hline & katolicy & prawosławni & niewierzący & innych wyznań \\
\hline Zdecydowanie tak & 47,1 & 22,3 & 47,3 & 57,9 \\
\hline Raczej tak & 35,7 & 55,4 & 33,0 & 34,2 \\
\hline Raczej nie & 12,2 & 14,3 & 11,0 & 5,3 \\
\hline Zdecydowanie nie & 3,0 & 4,5 & 5,5 & 0 \\
\hline Trudno powiedzieć & 1,9 & 3,6 & 3,3 & 2,6 \\
\hline \multicolumn{5}{|c|}{ Czy Twoim zdaniem roślinom przysługuje status moralny? } \\
\hline Zdecydowanie tak & 28,0 & 18,7 & 38,5 & 44,7 \\
\hline Raczej tak & 42,8 & 53,3 & 35,2 & 34,2 \\
\hline Raczej nie & 19,7 & 18,7 & 16,5 & 15,8 \\
\hline Zdecydowanie nie & 4,9 & 4,7 & 6,6 & 0 \\
\hline Trudno powiedzieć & 4,5 & 4,7 & 3,3 & 5,3 \\
\hline \multicolumn{5}{|c|}{ Czy Twoim zdaniem mikroorganizmom przysługuje status moralny? } \\
\hline Zdecydowanie tak & 16,2 & 1,9 & 20,0 & 21,6 \\
\hline Raczej tak & 35,4 & 26,4 & 35,6 & 29,7 \\
\hline Raczej nie & 32,7 & 42,5 & 31,1 & 29,7 \\
\hline Zdecydowanie nie & 8,5 & 14,2 & 8,9 & 5,4 \\
\hline Trudno powiedzieć & 7,3 & 15,1 & 4,4 & 13,5 \\
\hline
\end{tabular}




\begin{tabular}{|l|c|c|c|c|}
\hline \multicolumn{4}{|c|}{ Czy Twoim zdaniem przyrodzie nieożywionej przysługuje status moralny? } \\
\hline Zdecydowanie tak & 20,1 & 7,6 & 20,9 & 28,9 \\
\hline Raczej tak & 38,6 & 30,5 & 37,4 & 34,2 \\
\hline Raczej nie & 29,0 & 35,2 & 26,4 & 23,7 \\
\hline Zdecydowanie nie & 5,8 & 11,4 & 12,1 & 5,3 \\
\hline Trudno powiedzieć & 6,6 & 15,2 & 3,3 & 7,9 \\
\hline
\end{tabular}

Źródło: badania własne

Rozkład odpowiedzi przedstawiony w tabeli 5 wskazuje, że respondenci w przeważającej mierze skłonni byli przyznać status moralny zwierzętom, roślinom, a nawet mikroorganizmom i przyrodzie nieożywionej. Wyjątek stanowili jedynie studenci wyznania prawosławnego, których większość takiego statusu zarówno drobnoustrojom, jak i przyrodzie nieożywionej nie przyznałoby. Gwoli ścisłości należy wyjaśnić, iż status moralny rozumiany jest w tym przypadku jako cenność lub ważność określonego elementu stanowiącego wartość autoteliczną, a nie instrumentalną, i któremu z tego tytułu przysługuje szacunek ze strony człowieka (DeGrazia, 2002: 27). Odwołując się do wyników analizy danych zawartych w tabeli 5, warto zauważyć, że najwyższy odsetek pozytywnych odpowiedzi udzieliły osoby będące „innego wyznania”, czyli głównie protestanci oraz wierzący, choć niezwiązani z żadnym konkretnym Kościołem. Rachunek statystyczny umożliwia dokonanie dokładniejszej analizy w kwestii ewentualnego przyznania statusu moralnego mikroorganizmom, w wyniku której przeprowadzono test chi-kwadrat, uzyskawszy wartość $\chi^{2}(12)=32,028 ; p=0,001$. Otrzymany wynik jest istotny statystycznie, co pozwala przyjąć hipotezę, zgodnie z którą zmienna: deklarowana wiara koreluje z przejawianą skłonnością studentów do przydzielenia statusu moralnego drobnoustrojom. Wartość współczynnika kontyngencji wyniosła $C=0,247$, co świadczy o średniej sile związku między zmiennymi. W przypadku kolejnej kwestii, a mianowicie nadania wartości autotelicznej przyrodzie nieożywionej, wartość testu chi-kwadrat wyniosła $\chi^{2}(12)=28,540 ; p=0,005$. Taki wynik jest istotny statystycznie i tym samym pozwala na przyjęcie hipotezy, zgodnie z którą wyrażana przez respondentów chęć do nadania przyrodzie nieożywionej statusu moralnego zależała od wyznania, jakie deklarowali. Wartość współczynnika kontyngencji wyniosła $\mathrm{C}=0,234$, a zatem siłę związku między zmiennymi należy uznać za średnią. Warto ponadto zauważyć, że respondenci, którzy zgodzili się na wyniesienie różnych elementów przyrody do rangi wartości autotelicznej, po części opowiedzieli się również za założeniami egalitaryzmu gatunkowego. Pewien wyjątek stanowili jedynie badani wyznania prawosławnego, których większość prawdopodobnie nie przystałaby na równe traktowanie różnych elementów przyrody. 
Tabela 6. Dane dotyczące skłonności studentów do przydzielenia statusu moralnego wybranym elementom przyrody

\begin{tabular}{|c|c|c|}
\hline \multicolumn{3}{|c|}{$\begin{array}{c}\text { Czy Twoim zdaniem zwierzętom przysługuje status moralny? } \\
{[\%]}\end{array}$} \\
\hline & wieś & miasto \\
\hline Zdecydowanie tak & 37,7 & 48,4 \\
\hline Raczej tak & 42,3 & 35,6 \\
\hline Raczej nie & 14,2 & 9,3 \\
\hline Zdecydowanie nie & 3,2 & 4,0 \\
\hline Trudno powiedzieć & 2,5 & 2,7 \\
\hline \multicolumn{3}{|c|}{ Czy Twoim zdaniem roślinom przysługuje status moralny? } \\
\hline Zdecydowanie tak & 28,0 & 31,4 \\
\hline Raczej tak & 41,6 & 43,9 \\
\hline Raczej nie & 22,2 & 14,3 \\
\hline Zdecydowanie nie & 4,3 & 5,4 \\
\hline Trudno powiedzieć & 3,9 & 4,9 \\
\hline \multicolumn{3}{|c|}{ Czy Twoim zdaniem mikroorganizmom przysługuje status moralny? } \\
\hline Zdecydowanie tak & 12,0 & 17,4 \\
\hline Raczej tak & 34,8 & 31,1 \\
\hline Raczej nie & 34,4 & 33,8 \\
\hline Zdecydowanie nie & 10,1 & 8,7 \\
\hline Trudno powiedzieć & 8,7 & 9,1 \\
\hline \multicolumn{3}{|c|}{ Czy Twoim zdaniem przyrodzie nieożywionej przysługuje status moralny? } \\
\hline Zdecydowanie tak & 15,8 & 21,7 \\
\hline Raczej tak & 37,4 & 34,6 \\
\hline Raczej nie & 30,6 & 28,1 \\
\hline Zdecydowanie nie & 7,9 & 8,3 \\
\hline Trudno powiedzieć & 8,3 & 7,4 \\
\hline
\end{tabular}

Źródło: badania własne

Dane przedstawione w tabeli 6 prezentują interesujący rozkład odpowiedzi. W przypadku wszystkich zmiennych mieszkańcy miast stanowili wyższy odsetek osób opowiadających się za nadaniem poszczególnym elementom przyrody statusu moralnego niż mieszkańcy wsi, choć różnice w wyrażanych przez studentów opiniach były nieznaczne. Wartość testu chi-kwadrat w przypadku pierwszej zmiennej wyniosła $\chi^{2}(4)=7,575 ; p=0,108$. Wynik ten nakazuje odrzucić hipotezę zakładającą, iż zmienna: stałe miejsce zamieszkania koreluje $\mathrm{z}$ opiniami na temat przyznania zwierzętom statusu moralnego. W przypadku drugiej z wymie- 
nionych zmiennych wartość testu chi-kwadrat wyniosła $\chi^{2}(4)=5,340 ; \mathrm{p}=0,254$. Uzyskany w ten sposób wynik nie jest istotny statystycznie, co oznacza, iż konieczne jest odrzucenie hipotezy zakładającej, że zmienna: poglądy dotyczące nadania wartości autotelicznej roślinom zależą od miejsca zamieszkania respondentów. Z kolei dokładniejsza analiza trzeciej cechy, czyli możliwości przydzielenia statusu moralnego mikrobom, pozwoliła uzyskać w wyniku testu chi-kwadrat wartość $\chi^{2}(4)=3,309 ; \mathrm{p}=0,507$. Otrzymany wynik, podobnie jak w poprzednich przypadkach, oznacza, iż należy odrzucić hipotezę, zakładającą, że zmienna: stałe miejsce zamieszkania koreluje ze skłonnością badanych do nadania statusu moralnego mikroorganizmom. Przy kolejnym pytaniu dotyczącym ewentualnego wyniesienia przyrody nieożywionej do wartości autotelicznej, wartość testu chi-kwadrat wyniosła $\chi^{2}(4)=2,926 ; p=0,570$, a zatem i w tej kwestii należy odrzucić hipotezę zakładającą, że opinie respondentów odnośnie możliwego przyznania przyrodzie nieożywionej statusu moralnego zależą od zmiennej: stałe miejsce zamieszkania. Na podstawie danych z tabeli można również wnioskować, iż studenci mieszkający na stałe w mieście byli nieco bardziej skłonni popierać założenia egalitaryzmu gatunkowego niż mieszkańcy wsi, a także w wyższym stopniu przejawiali oni cechy osobowości środowiskowej.

Tabela 7. Dane dotyczące postrzegania przez badanych relacji człowiek-przyroda

\begin{tabular}{|l|c|c|c|c|}
\hline \multicolumn{3}{|c|}{ Które z przytoczonych twierdzeń jest Ci najbliższe? } \\
\hline & katolicy & prawosławni & niewierzący & $\begin{array}{c}\text { innych } \\
\text { wyznań }\end{array}$ \\
\hline $\begin{array}{l}\text { Bóg kazał człowiekowi czynić sobie Ziemię } \\
\text { poddaną, więc można ją bez ograniczeń } \\
\text { przekształcać i eksploatować. }\end{array}$ & 1,5 & 2,9 & 0 & 0 \\
\hline $\begin{array}{l}\text { Człowiek nie może bezmyślnie czerpać } \\
\text { z darów przyrody, gdyż jej jedynym Panem } \\
\text { jest Stwórca. }\end{array}$ & 1,9 & 4,8 & 0 & 0 \\
\hline $\begin{array}{l}\text { Przyroda jest darem danym od Boga, wią- } \\
\text { żącym się z odpowiedzialnością, do której } \\
\text { człowiek powinien się poczuwać i tym } \\
\text { samym rozsądnie korzystać z jej dobro- } \\
\text { dziejstw. }\end{array}$ & 42,6 & 26,0 & 2,2 & 32,5 \\
\hline $\begin{array}{l}\text { Człowiek jako najbardziej rozwinięta } \\
\text { w wyniku procesu ewolucji istota, dzięki } \\
\text { zdolnościom własnego intelektu i pracy } \\
\text { własnych rąk ma prawo do nieograniczo- } \\
\text { nego czerpania z zasobów natury. }\end{array}$ & 2,3 & 1,9 & 2,2 & 2,5 \\
\hline
\end{tabular}




\begin{tabular}{|l|l|l|l|l|}
\hline $\begin{array}{l}\text { Człowiek będący istotą moralną powinien } \\
\text { otaczać troską przyrodę, nie może on roś- } \\
\text { cić sobie prawa do bezgranicznego inge- } \\
\text { rowania w nią, powinien zatem korzystać } \\
\text { z jej bogactwa z umiarem. }\end{array}$ & 40,4 & 54,8 & 62,6 & 50,0 \\
\hline $\begin{array}{l}\text { Człowiek jest elementem przyrody i jego życie } \\
\text { wcale nie jest więcej warte niż życie zwierzę- } \\
\text { cia czy rośliny, tym samym ludzie nie powin- } \\
\text { ni przedkładać swoich potrzeb nad potrzeby } \\
\text { innych istot, co więcej powinni je ograniczać. }\end{array}$ & 11,3 & 9,6 & 33,0 & 15,0 \\
\hline
\end{tabular}

Źródło: badania własne

Interesujący rozkład odpowiedzi zaprezentowany został również w tabeli 7 . Zgodnie $z$ analizą zamieszczonych w niej danych można pokusić się o stwierdzenie, że deklaracja części badanych, iż są katolikami, nie oznaczała jeszcze, że relacje człowieka do przyrody najtrafniej według nich opisuje twierdzenie religijne i moralne zarazem. Zbliżony odsetek studentów, stanowiących również osoby wyznania katolickiego, opowiedziało się za twierdzeniem moralnym, choć areligijnym. Co więcej, prawie co dziesiąty katolik wybierał twierdzenie zawierające założenia egalitaryzmu gatunkowego. W przypadku studentów wyznania prawosławnego i badanych innych wyznań różnice te są jeszcze większe. Z kolei respondenci uznający się za osoby niewierzące najczęściej wybierali twierdzenie moralne i areligijne, rzadziej natomiast wskazywali na twierdzenie dotyczące egalitaryzmu gatunkowego. Niewierzący stanowili najwyższy odsetek osób opowiadających się właśnie za równym traktowaniem wszelkich gatunków żyjących na Ziemi. Prawdopodobnie respondenci ci przejawiali również w wyższym niż pozostali stopniu, cechy charakterystyczne dla osobowości środowiskowej, takie jak: skromność, uczuciowość, tolerancyjność czy życzliwość dla innych istot. Warto podkreślić, że osoby niewierzące nie wybierały twierdzenia religijnego i moralnego zarazem, podczas gdy katolicy równie często wskazywali na odpowiedź areligijną i moralną. Ogólnie można stwierdzić, że najczęściej wybieranym twierdzeniem przez respondentów - z wyjątkiem katolików - była odpowiedź, zgodnie z którą człowiek ma prawo czerpać z zasobów natury, ale wyłącznie w stopniu umiarkowanym.

Tabela 8. Dane dotyczące postrzegania przez badanych relacji człowiek-przyroda

\begin{tabular}{|c|c|c|}
\hline \multicolumn{3}{|c|}{$\begin{array}{c}\text { Które z przytoczonych twierdzeń jest Ci najbliższe? } \\
{[\%]}\end{array}$} \\
\hline & wieś & miasto \\
\hline $\begin{array}{l}\text { Bóg kazał człowiekowi czynić sobie Ziemię poddaną, więc moż- } \\
\text { na ją bez ograniczeń przekształcać i eksploatować. }\end{array}$ & 0,4 & 2,7 \\
\hline
\end{tabular}




\begin{tabular}{|l|c|c|}
\hline $\begin{array}{l}\text { Człowiek nie może bezmyślnie czerpać z darów przyrody, gdyż } \\
\text { jej jedynym Panem jest Stwórca. }\end{array}$ & 2,9 & 1,3 \\
\hline $\begin{array}{l}\text { Przyroda jest darem danym od Boga, wiążącym się z odpowie- } \\
\text { dzialnością, do której człowiek powinien się poczuwać i tym sa- } \\
\text { mym rozsądnie korzystać z jej dobrodziejstw. }\end{array}$ & 36,0 & 24,6 \\
\hline $\begin{array}{l}\text { Człowiek, jako najbardziej rozwinięta w wyniku procesu ewo- } \\
\text { lucji istota, dzięki zdolnościom własnego intelektu i pracy włas- } \\
\text { nych rąk ma prawo do nieograniczonego czerpania z zasobów } \\
\text { natury. }\end{array}$ & 1,8 & 2,7 \\
\hline $\begin{array}{l}\text { Człowiek, będący istotą moralną, powinien otaczać troską } \\
\text { przyrodę, nie może on rościć sobie prawa do bezgranicznego } \\
\text { ingerowania w nią, powinien zatem korzystać z jej bogactwa } \\
\text { z umiarem. }\end{array}$ & 46,0 & 50,9 \\
\hline $\begin{array}{l}\text { Człowiek jest elementem przyrody i jego życie wcale nie jest } \\
\text { więcej warte niż życie zwierzęcia czy rośliny, tym samym ludzie } \\
\text { nie powinni przedkładać swoich potrzeb nad potrzeby innych } \\
\text { istot, co więcej powinni je ograniczać. }\end{array}$ & 12,9 & 17,9 \\
\hline
\end{tabular}

Źródło: badania własne

Dane zobrazowane w tabeli 8 wskazują, iż najczęściej wybieraną przez ogół badanych odpowiedzią, podobnie jak w przypadku zmiennej: deklarowane wyznanie, było twierdzenie areligijne i moralne jednocześnie. Wyższy odsetek osób badanych, stanowiących w tym przypadku mieszkańców wsi, wybierało twierdzenie religijne i moralne. Z kolei mieszkańcy miast częściej wskazywali na odpowiedź areligijną i moralną jednocześnie, a także twierdzenie odnoszące się do założeń egalitaryzmu gatunkowego. Prawdopodobnie studenci ci przejawiali również w większej mierze niż respondenci zamieszkujący wieś cechy osobowości środowiskowej. W porównaniu $\mathrm{z}$ danymi $\mathrm{z}$ tabeli 7 można stwierdzić, że zdeklarowane przez respondentów wyznanie - z wyłączeniem osób niewierzących - nie korelowało $\mathrm{z}$ wyborem twierdzenia religijnego, natomiast wybór ten w pewnej mierze zależał od zamieszkiwania badanych na terenach wiejskich. Z kolei zmienna w postaci bycia osobą niewierzącą korelowała z opowiadaniem się za twierdzeniem areligijnym. Częstszy wybór tej odpowiedzi zależał też od zamieszkiwania respondentów w mieście.

\section{Zakończenie}

Podsumowując, w wyniku zrealizowanych badań socjologicznych i dokonanej analizy zebranych danych można wnioskować, że poziom rozwoju inteligencji środowiskowej wśród studentów z wybranych państw Europy Środkowej i Wschodniej 
jest stosunkowo niski. W wyniku głębszej refleksji można stwierdzić, że studenci w toku studiów raczej nie są poddawani procesowi mającemu na celu pobudzanie tego rodzaju inteligencji, co więcej, oni sami również nie zabiegają o to, by ten stan rzeczy zmienić - prawdopodobnie nie odczuwają w ogóle takiej potrzeby. Z drugiej jednak strony dostrzegalne jest $\mathrm{u}$ badanych zainteresowanie sprawami ochrony środowiska i potrzeba troski o przyrodę. Te ogólne spostrzeżenia nie przekładają się jednak na głębszy wymiar, który mógłby znaleźć odzwierciedlenie chociażby $\mathrm{w}$ rozwoju ich środowiskowej inteligencji. O pewnym potencjale do pobudzenia tej zdolności umysłu może po części świadczyć stosunkowo wysoki odsetek wskazań dotyczący motywu troski o przyrodę, jakim jest chociażby chęć zachowania życia na Ziemi. Ten jeden pozytyw to wciąż za mało, by inteligencja środowiskowa zyskała mocne podstawy do swego rozwoju; niemniej, jeśli tylko ten potencjał młodych ludzi zostanie dostrzeżony, jest szansa, że w wyniku podjęcia wysiłku tak ze strony otoczenia społecznego, jak i wewnętrznej mobilizacji każdej jednostki, stan tej inteligencji poprawi się w dłuższej perspektywie.

W celu podjęcia się wspomnianego zadania konieczne jest wstępne określenie obecnego stanu inteligencji środowiskowej i stopnia przejawianych przez studentów cech osobowości środowiskowej. To zadanie wymaga z kolei odwołania się chociażby do analizowanych w tekście danych. Podkreślić jednak należy, że próba określenia poziomu inteligencji środowiskowej nie poddaje się prostej analizie nie tylko dlatego, że jest to zagadnienie bardzo złożone, ale także z tego powodu, że odsetek studentów przejawiających wyższy poziom inteligencji i cech osobowości środowiskowej, był bardzo niski. Ponadto należy pamiętać, że ich stan może również zależeć od innych, niewspomnianych w artykule czynników.

Poczynając od pierwszego kryterium, jakie zostało uwzględnione w tekście, a mianowicie: wyznania deklarowanego przez studentów, należy zauważyć, że w przypadku kwestii holistycznego sposobu myślenia badanych o środowisku, wyniki nie są jednoznaczne. Przy pytaniu dotyczącym obaw związanych z zagrożeniami przyrodniczymi najbardziej holistyczny sposób myślenia przejawiali katoliccy i studenci prawosławni, natomiast przy pytaniu o motywy skłaniające do troski o przyrodę $\mathrm{w}$ najwyższym stopniu myślenie $\mathrm{w}$ kategoriach holistycznych zaprezentowali z kolei niewierzący i badani innych wyznań. W przypadku kwestii dotyczącej ewentualnego przypisania statusu moralnego poszczególnym elementom przyrody najliczniej opowiedzieli się za tym badani określający się jako osoby innego wyznania; najmniej skłonni, by nadać taki status przyrodzie, byli natomiast badani wyznania prawosławnego. Tym samym ci pierwsi stanowili wyższy odsetek osób aprobujących założenia egalitaryzmu gatunkowego niż ci drudzy. Zarówno studenci katolicy, jak i prawosławni wyrażali również największe obawy 
co do obecnego i przyszłego stanu przyrody, którym towarzyszył prawdopodobnie niepokój, strach, niepewność i stres. Ten wyższy poziom lęku spowodowany istniejącymi zagrożeniami w świecie przyrody w ogólnym rozrachunku wywoływał wśród tych studentów dość powszechny pesymizm społeczny. Wspomniane negatywne emocje $\mathrm{z}$ mniejszym nasileniem przejawiały się u pozostałych badanych, co z kolei wyrażało się u nich $\mathrm{w}$ niższym poziomie prezentowanego pesymizmu społecznego. Ponadto warto zwrócić uwagę, że ten, przejawiany przez znaczną część badanych, pesymizm nie korelował w sposób jednoznaczny z cechami osobowości środowiskowej takimi jak: otwartość, uczuciowość, skromność, ugodowość, empatia czy życzliwość wobec innych - nie tylko ludzkich istot. Na rzecz tej tezy może świadczyć fakt, że w porównaniu do katolików i studentów prawosławnych nieco wyższy odsetek respondentów stanowiących osoby niewierzące przejawiało cechy osobowości środowiskowej. Ponadto najwyższy odsetek studentów, którzy opowiedzieli się za założeniami egalitaryzmu gatunkowego, stanowiły osoby niewierzące, najniższy natomiast właśnie badani wyznania katolickiego i prawosławnego. Studenci ci najliczniej opowiedzieli się również za instrumentalnym traktowaniem przyrody. Większy altruizm w tym względzie wykazały natomiast osoby niewierzące i przyznające się do innych wyznań. Z kolei w przypadku cech osobowości środowiskowej i zdolności umysłu skierowanej ku ochronie przyrody związek niewątpliwie istnieje, choć jest on dość słaby. Sformułowanie takiej tezy może wynikać z faktu, iż samo przejawianie wrażliwości w stosunku do przyrody nie stanowi jeszcze komponentu inteligencji środowiskowej, by można o niej zasadnie mówić - co warto podkreślić - konieczne jest poznanie i zrozumienie tej uczuciowości. Pogląd ten w pewnym stopniu potwierdza spostrzeżenie, że o ile pewna część badanych wskazywała na wewnętrzną wartość samej przyrody, jako główny motyw troski o nią, o tyle znikomy odsetek osób - z wyjątkiem katolików - opowiadał się za taką wartością, jaką jest piękno przyrody. Uwaga ta nie przesądza jednak do końca, z jaką świadomością badani przystępowali do udzielania odpowiedzi. Niewykluczone, że dopiero odczytanie pytań w kwestionariuszu pobudziło myślenie i świadomość wśród studentów. Ponadto nie można również wykluczyć, że celowo nie wypowiadali się oni szczerze, chcąc na przykład zaprezentować się w określony sposób.

Odnosząc się z kolei do drugiego kryterium, stanowiącego stałe miejsce zamieszkania, należy zauważyć, że zbliżony odsetek tak mieszkańców wsi, jak i miast wykazywał tendencję do myślenia w kategoriach holistycznych. Przy czym, ci drudzy tylko nieco częściej opowiadali się za traktowaniem środowiska w sposób instrumentalny. Ponadto nieznacznie wyższy odsetek studentów zamieszkujących wieś niż miasto wyrażało obawy, niepokój i strach wobec zagrożeń środowiskowych i konsekwencji 
tego stanu rzeczy. Nie zmienia to jednak, że większość osób badanych - bez względu na miejsce zamieszkania - przejawiało pesymizm społeczny w kwestii zmian klimatu i przyszłej egzystencji gatunku ludzkiego. Na szczególną uwagę zasługuje zagadnienie ewentualnego przypisania poszczególnym elementom przyrody statusu moralnego. Mimo iż nie było znacznych różnic w proporcji wskazań, jednak konsekwentnie za nadaniem wartości autotelicznej różnym obiektom przyrodniczym opowiadało się więcej mieszkańców miasta niż wsi. Z kolei w przypadku postrzegania relacji człowiek-przyroda respondenci najczęściej wybierali dwa twierdzenia - oba moralne, przy czym jedno religijne, a drugie areligijne. Wyższy odsetek mieszkańców wsi stanowili respondenci, którzy wybierali to pierwsze twierdzenie, natomiast tę drugą odpowiedź wskazywała większa liczba mieszkańców miasta. Studenci zamieszkujący na stałe w mieście częściej również opowiadali się za egalitaryzmem gatunkowym, co po części potwierdzają wyniki dotyczące wyrażanej gotowości do nadania przyrodzie statusu moralnego. Najprawdopodobniej respondenci ci stanowili też wyższy odsetek osób przejawiających pewne cechy osobowości środowiskowej, takie jak: otwartość, uczuciowość, skromność, tolerancyjność czy pozytywny stosunek do innych sworzeń. Można tym samym wnioskować, że studenci zamieszkujący tereny wiejskie przejawiali większy deficyt tych cech. Wspomniane cechy osobowości środowiskowej, podobnie jak przy poprzedniej zmiennej, nie wykazywały jednoznacznego związku z prezentowanym przez studentów pesymizmem społecznym. Świadczy o tym fakt, że mieszkańcy miasta tylko nieco bardziej przejawiali te cechy, natomiast mieszkańcy wsi wykazywali jedynie nieznacznie wyższy poziom pesymizmu. Analogicznie jak przy zmiennej: deklarowane wyznanie i w tym przypadku dostrzegalny jest pewien związek między cechami osobowości środowiskowej badanych a inteligencją środowiskową, ale również jest on dość luźny. Świadczy o tym chociażby rozkład odpowiedzi przy pytaniu o motywy, gdy mieszkańcy miasta częściej deklarowali gotowość do ochrony środowiska ze względu na dobro zwierząt oraz wewnętrzną wartość samej przyrody, natomiast mieszkańcy wsi - ze względu na jej piękno.

Dokonany bilans pozwala na koniec sformułować wniosek, że nieco wyższy poziom inteligencji środowiskowej przejawiali studenci zamieszkujący miasto niż wieś z kolei w przypadku kryterium: deklarowane wyznanie. Sprawa jest trochę bardziej złożona, niemniej można pokusić się o stwierdzenie, że nieznacznie bardziej rozwiniętą inteligencję środowiskową zaprezentowały osoby niewierzące i te, które przyznały się do innych wyznań, niż respondenci wyznania katolickiego i prawosławnego. W celu pełniejszego zobrazowania niniejszego zagadnienia warto również nadmienić, że 57,2\% przebadanych katolików to osoby zamieszkujące wieś, natomiast $42,8 \% \mathrm{z}$ nich stanowili mieszkańcy miasta. W przypadku studen- 
tów wyznania prawosławnego proporcje przedstawiały się następująco - 67,8\% mieszkańcy wsi i 32,2\% - mieszkańcy miasta, z kolei 66,3\% osób niewierzących stanowili badani na stałe mieszkający w mieście, natomiast 33,7\% studentów stanowili niewierzący zamieszkujący wieś. $Z$ kolei, jeśli chodzi o osoby innych wyznań, proporcje rozkładały się po równo.

Znając zatem obecny poziom inteligencji środowiskowej młodych ludzi, $\mathrm{w}$ celu jego poprawienia konieczne jest przystąpienie do kształtowania w sobie nowej wrażliwości na różnorakie zagrożenia przyrodnicze i nauczenie się, co z nimi zrobić. Samo doświadczanie przyrody, podobnie jak i sama teoretyczna wiedza, nie są warunkami koniecznymi dla powstania i rozwoju inteligencji środowiskowej. Należy jednak zauważyć, że wiedza naukowa pozwala świadomie obcować z przyrodą i właściwie o nią dbać. Jak uczy doświadczenie, ludzie chętniej szanują to, co rozumieją. Z kolei doświadczanie przyrody poprzez odbiór wszelkimi zmysłami wysyłanych przez nią bodźców pozwala wyrabiać u człowieka uważność. W celu zrozumienia i uwrażliwienia na jej stan konieczne jest zatem dostrojenie się do życia w harmonii z naturą, zrozumienie wpływu człowieka na kondycję środowiska naturalnego, w czym pomocne powinny być: poza wspomnianą wiedzą i doświadczeniem przyrody, przyswojone wartości ekologiczne i przejawiane cechy charakterystyczne dla osobowości środowiskowej.

Sformułowane wnioski skłaniają do końcowej, następującej refleksji, a mianowicie, że młodzi ludzie na ogół nie odczuwają związku z przyrodą, odcinają się od niej nie tylko na płaszczyźnie poznawczej, ale również emocjonalnej, co w pewnym sensie może być zrozumiałe, jeśli oznaczałoby jednoczesne odseparowanie się od źródła cierpienia, jakie mogą stanowić istniejące zagrożenia środowiskowe. Niemniej taki stan rzeczy nie do końca wynika z ich winy, po części ponosi ją również otoczenie społeczne, wspólnie można jednak temu zaradzić. Jeśli mimo to człowiek nadal będzie unikał przyjęcia na siebie odpowiedzialności za stan przyrody, jej kondycja będzie się pogarszała, podobnie zresztą jak sama kondycja współczesnego człowieka.

\section{Literatura}

Czartoszewski J. (red.). (2001). Edukacja ekologiczna na progu XXI wieku. Stan - możliwości - prognozy. Warszawa.

DeGrazia D. (2002). Animal Rights: A Very Short Introduction. Oxford.

Gardner H. (1983). Frames of Mind: The Theory of Multiple Intelligences, New York.

Goldberg L.R. (1993). The structure of phenotypic personality traits. "American Psychologist" vol. 48, no 1, s. 26-34. 
Goleman D. (2009). Ecological Intelligence: How Knowing the Hidden Impacts of What we Buy Can Change Everything. New York.

Gottfredson L. (1997). Mainstream Science Intelligence: an editorial with 52 signatories history and bibliography. "Intelligence" 24(1), s. 13-23.

Kalinowska A. (1993). Ekologia: wybór przyszłości. Warszawa.

Louv R. (2005). Last Child in the Woods: Saving Our Children from Nature-Deficit Disorder. London. McCrae R.R., Costa P.T. (1995). Trait explanations in personality psychology. "European Journal of Personality" no 9, s. 231-252.

Nęcka E. (2003). Inteligencja. Geneza - Struktura - Funkcje. Gdańsk.

Squalli J. (2014). Intelligence and environmental emissions. "Intelligence" no 44, s. 33-39.

Strelau J., Doliński D. (red.). (2010). Psychologia akademicka, t. 1. Gdańsk 